\title{
The effect of obesity in laparoscopic transperitoneal adrenalectomy
}

\author{
Önder Altın(D), Ramazan Sarı(D) \\ Clinic of General Surgery, Kartal Dr. Lütfi Kırdar City Hospital, Istanbul, Turkey
}

\begin{abstract}
Objective: Laparoscopic adrenalectomy is the gold standard for the resection of adrenal tumors. However, there are some technical difficulties, which may be due to the fact that adrenalectomy is rarely encountered in general surgery practice and has a high learning curve. In addition to these, obesity is another problem in laparoscopic adrenalectomies. In the present study, it was aimed to evaluate whether obesity affects perioperative and postoperative complications after laparoscopic adrenalectomy.
\end{abstract}

Material and Methods: This is a retrospective comparative study carried out between December 2008 and June 2018. A total of 65 patients who underwent laparoscopic transperitoneal adrenalectomy were divided into two groups according to their Body Mass Index (BMI). Patients' demographic data, perioperative and postoperative results were analyzed from hospital medical records.

Results: There were 30 non-obese and 35 obese patients. There was no significant difference between obese and non-obese patients in terms of operation time, peroperative complications and length of hospital stay. However, there was a statistically significant difference between the two groups for postoperative complications $(p<0.031)$. There was conversion to open surgery in four obese patients and in one patient in the non-obese group.

Conclusion: In obese patients, technical difficulties may be encountered during surgery due to increased adipose tissue, and postoperative complication rates may increase. Nevertheless, laparoscopic transperitoneal adrenalectomy can be performed safely paying attention to the management of obesity-related complications.

Keywords: Adrenalectomy, body mass index, laparoscopy, obesity

Cite this article as: Altın Ö, Sarı R. The effect of obesity in laparoscopic transperitoneal adrenalectomy. Turk J Surg 2021; 37 (2): 126-132

\section{Corresponding Author}

Ramazan Sarı

E-mail: sariramazan71@gmail.com

Received: 05.06.2020

Accepted: 07.03.2021

Available Online Date: 30.06 .2021

O Copyright 2021 by Turkish Surgical Society Available online at www.turkjsurg.com

DOI: 10.47717/turkjsurg.2021.4901

\section{INTRODUCTION}

Since the first laparoscopic adrenalectomy (LA) was done by Gagner et al. in 1992, laparoscopic removal of adrenal lesion has become the gold standard for the surgical management of most adrenal tumors (1). Current indications for $L A$ are similar to open adrenalectomy and include all functional adrenal tumors; pheochromocytoma, aldosteronoma, cortisol producing adenoma (Cushing syndrome), bilateral adrenal hyperplasia secondary to Cushing's disease or ectopic ACTH production. Suspicious malignant tumors of the adrenal gland smaller than $5-6 \mathrm{~cm}$ in diameter, adrenal metastasis, primary adrenocortical carcinoma, symptomatic angiomyolipomas or cysts, and incidentalomas are the other indications of LA (2). Diagnosis of adrenal masses have increased with the advancement of diagnostic modalities in the last few decades. Laparoscopic adrenalectomy has gained popularity as time passed due to favorable operative field, fewer complications, decreased morbidity, better cosmetic result, less postoperative pain, faster recovery, shorter hospital stay and earlier return to daily activities (3). Several techniques have been described, the most popular are laparoscopic lateral transabdominal approach, posterior retroperitoneoscopic adrenalectomy and robotic adrenalectomy (4-6). Adrenalectomies are not common operations in general practice, so the surgery should be performed in centers with endocrine surgery experience.

Worldwide, it is estimated that there are approximately 1.9 billion overweight people, and of these, more than 650 million are obese. The prevelance of obesity approximately tripled between 1979 and 2016. Body mass index (BMI) is generally used for the diagnosis of obesity, a person's weight (in kilograms) divided by 
the square of height (in meters). The diagnostic criteria of World Health Organization (WHO) for obesity is defined as $\mathrm{BMI} \geq 30$ $\mathrm{kg} / \mathrm{m}^{2}$ (7). Obesity is often considered as a main factor for prolonged operation time, increased blood loss, septic complications and wound infection (8-10). In open surgery, visualization of the surgical field in obese patients is a major problem due to extensive of adipose tissue. In order to overcome this problem, larger incision is required. Obese patients suffer more pain and restriction for longer time due to large abdominal incision. Therefore, there is increased risk of atelectasis and other pulmunary complications in these patients $(11,12)$. Moreover, obesity causes increased risk of wound infections as adipose tissue is hypoperfused and poorly oxygenated (13). Prolonged hospitalization is mostly due to worse perioperative and postoperative complications.

The aim of this study was to evaluate surgical outcomes of laparoscopic transperitoneal adrenalectomies performed in obese and non-obese patients.

\section{MATERIAL and METHODS}

In all patients, indications for surgery were according to the American Endocrine Surgeons and Endocrinologs guidelines; adrenal incidentalomas larger than $4 \mathrm{~cm}$ in diameter, functional tumors of any size (Cushing's syndrome, pheochromocytoma, Conn's syndrome or sex hormone producing tumor), and solitary adrenal metastases. Exclusion criteria included patients deemed high risk for laparoscopy by anesthesia and malignant tumors with radiological evidence of invasion of surrounding organs and tissues.
In this study, we divided the patients into 2 groups according to BMl: non-obese group $\left(\mathrm{BMl}<30 \mathrm{~kg} / \mathrm{m}^{2}\right)$ and obese group $\left(B M l \geq 30 \mathrm{~kg} / \mathrm{m}^{2}\right)$. All patients were assessed for the following parameters: demographics, indication for operation (preoperative diagnosis), tumor location, size, operation time, peroperative complications, conversion to open surgery, postoperative complications, hospital stay and postoperative histology.

\section{Surgical Technique}

A lateral transabdominal technique was used for all laparoscopic adrenalectomies. The patients were placed in a lateral decubitis position with the tumor side up and the table flexed between the 12. rib and iliac crest. Four trocars were used for right-sided adrenalectomies (Figure 1), three trocars were used in almost all patients for left-sided adrenalectomies (only one patient needed four trocars) (Figure 2). A thirty-degree laparoscope was used in all the cases and pneumoperitoneum was maintained at 12-14 $\mathrm{mmHg}$ by insuflation with carbon dioxide $\left(\mathrm{CO}_{2}\right)$. On the right side, the right lobe of the liver was mobilized to expose the inferior vena cava, and the triangular ligament was divided before placement of a liver retraction. Sharp and blunt dissection starts at the medial to the lateral edge of liver. Precaution is necessary to the vena cava inferior due to short course of adrenal vein. For the left sided adrenal gland tumor, the spleen, splenocolic ligament, and splenorenal ligament were dissected, and the tail of pancreas was mobilized to the medial on left side. Care is necessary to differentiate (not confuse) adrenal with the tail of pancreas because of similar tissue appearance, especially in obese patients. All specimens were placed in an endobag to be removed.

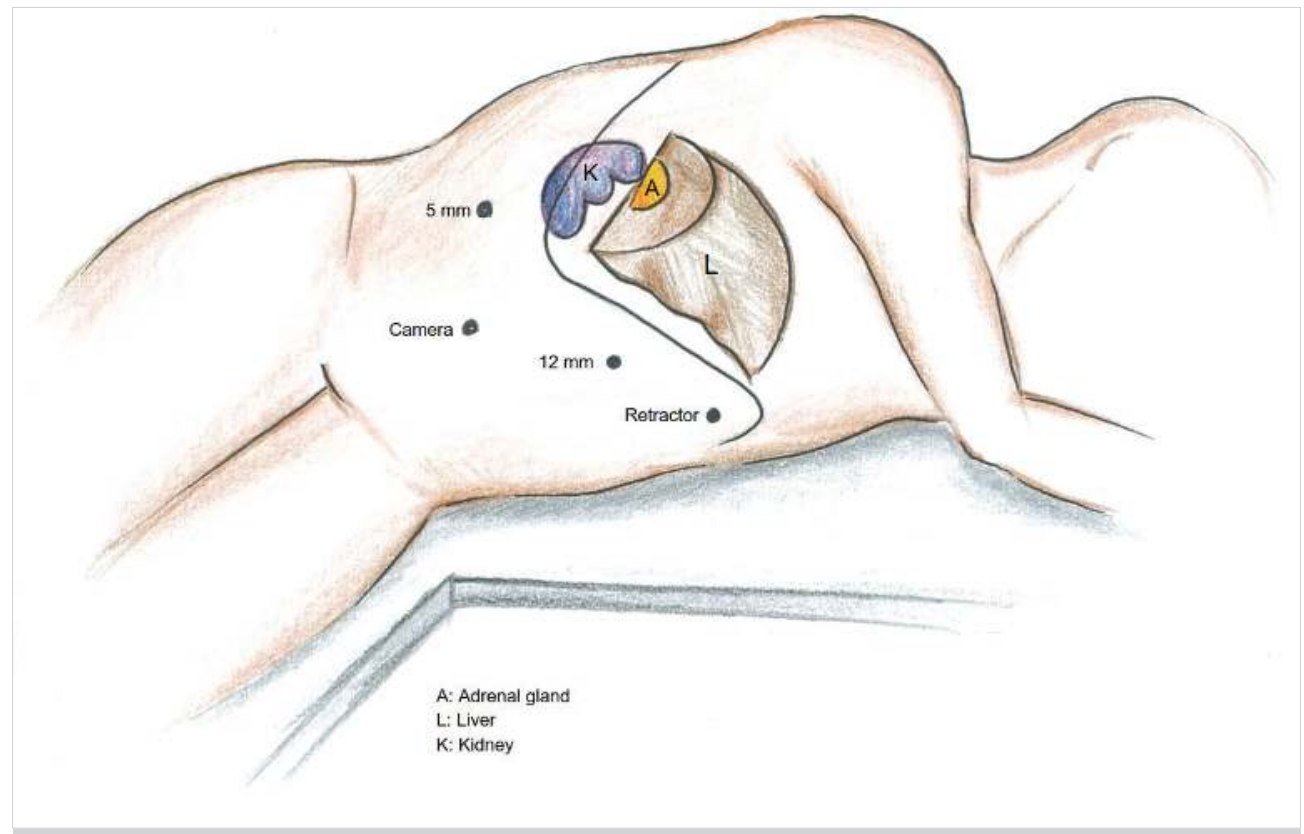

Figure 1. Trocar placement of right adrenalectomy. 


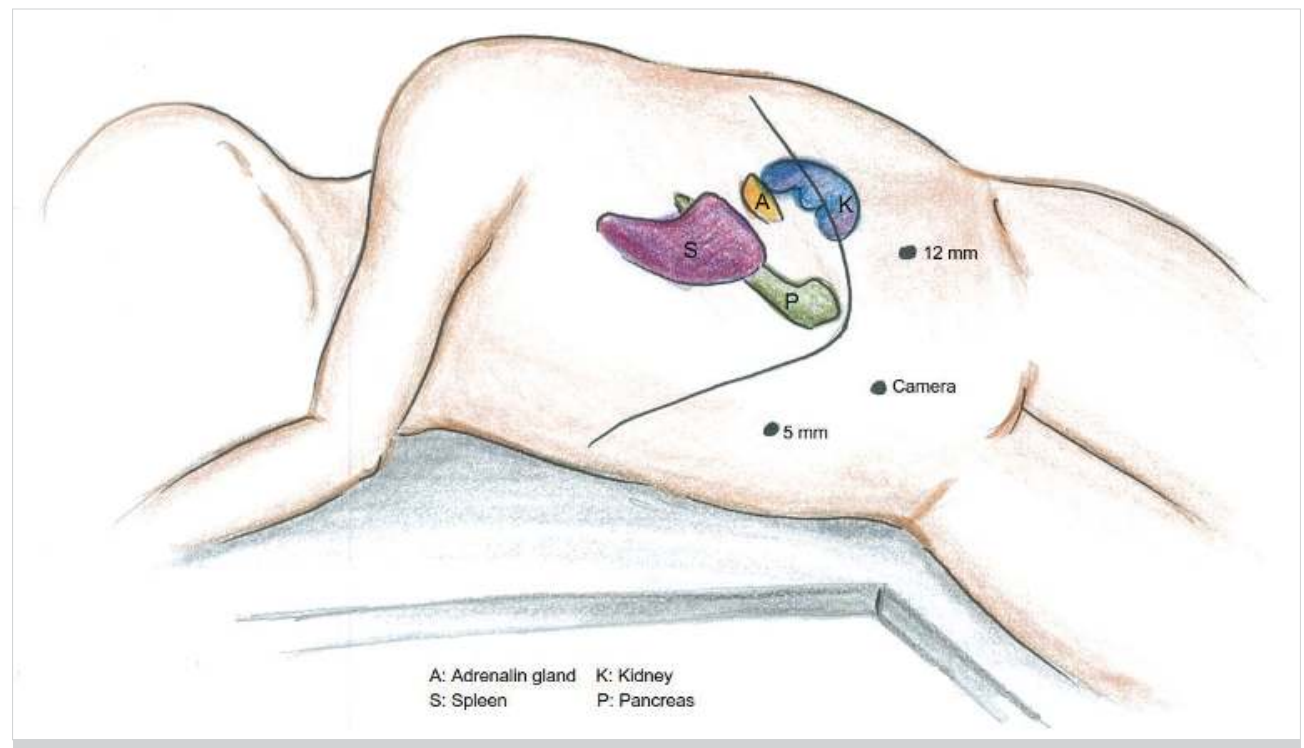

Figure 2. Trocar placement of left adrenalectomy.

\section{Statistical Analysis}

Data analysis and management were performed using SPSS for Windows ver. 21.0 software program (SPSS Inc., Chicago, IL). The data are expressed as mean \pm standard deviation or number (\%). Differences between parameters were compared with the Fisher's exact test, Chi-square test $\left(x^{2}\right)$ and Mann-Whitney $U$ test. All $p$ values $<0.05$ were considered statistically significant.

\section{RESULTS}

A total of 65 patients (44 females and 21 males) underwent laparoscopic transperitoneal adrenalectomy. Patients were divided into two groups according to the $\mathrm{BMl}$; non-obese $(\mathrm{BMl}<30$ ) and obese group $\geq 30 \mathrm{~kg} / \mathrm{m}^{2}$. The study included thirty (46.1\%) patients in the non-obese group and 35 (53.9\%) patients in the obese group. Mean age of the obese and non-obese group were $53( \pm 9.9)$ and $47.6( \pm 14.7)$ years, respectively. Mean tumor size of the obese group was $4.7( \pm 1.8) \mathrm{cm}$ and $4.7( \pm 2.8) \mathrm{cm}$ of the nonobese group. Preoperative diagnoses were Conn's and Cushing's syndrome $(41$ out of $65,63 \%)$ in most of the patients. There were 25 and 32 comorbidities in the non-obese and obese group respectively, most of these comorbidities were hypertension and diabetes mellitus (Table 1).

There was no statistically significant difference between the obese and non-obese groups when we compared operation time, peroperative complication and length of hospital stay. Mean operative time was $90.5 \pm 21.4$ minutes in the non-obese group and $100 \pm 24$ minutes in the obese group. In the nonobese patients group, four peroperative complications (major bleeding from surgical field) occured, and in one patient conversion to lapatoromy was needed due to bleeding from right median adrenal vein. Major bleeding from surgical field was seen in five patients from the obese group and in two patients (of these patients) we performed laparotomy due to inferior vena cava injury and intractable adrenal artery bleeding. The rate of conversion to laparotomy was $11.4 \%$ in the obese group and $3.3 \%$ in the non-obese group. The reasons of conversion to laparotomy were dense adhesions in two patients, profuse bleeding in two patients (one in non-obese and the other in obese group) and inferior vena cava injury in one patient. In patients who were converted to laparotomy, surgery was completed without any intraoperative mortality. In four obese patients, pleural effusion (two patients), deep vein trombosis, and major postoperative hemorrhage requiring blood transfusion were seen as postoperative complications. Only one patient in the non-obese group needed blood transfusion postoperatively.

There was a statistically significant difference between two groups for postoperative complications ( $p<0.031)$. Postoperative complications were classified according to the Clavien-Dindo classifications. According to Clavien-Dindo classification; in the non-obese group, one patient had class 2 (blood transfusion), in the obese group, seven patients had class 2 (three blood transfusuions, two pleural effusions, one upper extremity microemboli and one deep vein trombosis) and one patient had class five complication. Although all patients were given deep vein thrombosis prophylaxis and anti-embolic stockings, one patient in the obese group died due to cardiopulmonary arrest (Table 2).

Postoperative histopathological diagnoses are listed in Table 3. Cortex adenoma was reported in most of patients (17 patients (56.6\%) in non-obese and 28 patients (80\%) in obese group). There was a case of cortex carcinoma in each group. Three patients, who previously underwent pneumonectomy for lung cancer, had radiologically confirmed isolated adrenal metastasis. These three pateints were in the non-obese group, and their 
Table 1. Patients' characteristics

\begin{tabular}{|c|c|c|c|}
\hline & $<30 \mathrm{~kg} / \mathrm{m}^{2}$ & $\geq 30 \mathrm{~kg} / \mathrm{m}^{2}$ & \\
\hline & $(n=30)$ & $(n=35)$ & p \\
\hline Age & $47.6 \pm 14.7$ & $53.0 \pm 9.9$ & 0.097 \\
\hline Female & 15 & 29 & 0.007 \\
\hline Male & 15 & 6 & \\
\hline ASA & & & 0.072 \\
\hline ASA 2 & 14 & 23 & \\
\hline ASA 3 & 11 & 17 & \\
\hline \multicolumn{4}{|l|}{ Tumor location } \\
\hline Right & 17 & 14 & 0.218 \\
\hline Left & 13 & 21 & \\
\hline Tumor size & $4.7 \pm 2.8$ & $4.7 \pm 1.8$ & 0.993 \\
\hline Conn & 8 & 9 & \\
\hline Cushing & 4 & 18 & \\
\hline Cushing + hyperandrogenism & 0 & 1 & \\
\hline Cushing + cholelithiasis & 1 & 0 & \\
\hline Pheochromocytoma & 4 & 2 & \\
\hline Pheochromocytoma + myolipoma & 1 & 0 & \\
\hline Hyperandrogenism & 1 & 0 & \\
\hline Incidentoloma & 8 & 5 & \\
\hline Metastasis & 3 & 0 & \\
\hline Morbidity & & & 0.455 \\
\hline No & 5 & 3 & \\
\hline Yes & 25 & 32 & \\
\hline
\end{tabular}

Table 2. Perioperative and postoperative results

\begin{tabular}{|c|c|c|c|}
\hline & Non-obese $(n=30)$ & Obese $(n=35)$ & $\mathrm{p}$ \\
\hline Operation time & $90.5 \pm 21.4$ & $100 \pm 24.0$ & 0.100 \\
\hline Perioperative complications & & & 1.000 \\
\hline No & 26 & 30 & \\
\hline Yes & 4 & 5 & \\
\hline Bleeding & 4 & 4 & \\
\hline Vena cava inferior injury & 0 & 1 & \\
\hline Conversion to open surgery & 1 & 4 & 0.362 \\
\hline Right & 1 & 3 & \\
\hline Left & 0 & 1 & \\
\hline Postoperative complications & & & 0.031 \\
\hline No & 29 & 27 & \\
\hline Yes & 1 & 8 & \\
\hline Clavien-Dindo Class 2 & 1 & 7 & \\
\hline Blood transfusion & 1 & 3 & \\
\hline Pleural effusion & 0 & 2 & \\
\hline Microembolism of Upper extremity & 0 & 1 & \\
\hline Deep vein thrombosis & 0 & 1 & \\
\hline Clavien-Dindo Class 5 & 0 & 1 & \\
\hline Length of hospital stay, mean \pm SD (days) & $2.5 \pm 1.3$ & $3.1 \pm 1.3$ & 0.089 \\
\hline
\end{tabular}


Table 3. Postoperative histopathology

\begin{tabular}{|c|c|c|}
\hline & $\begin{array}{c}<30 \mathrm{~kg} / \mathrm{m}^{2} \\
(\mathrm{n}=30)\end{array}$ & $\begin{array}{c}\geq 30 \mathrm{~kg} / \mathrm{m}^{2} \\
(\mathrm{n}=35)\end{array}$ \\
\hline Cortical adenoma & 17 & 28 \\
\hline Cortical adenoma + myolipoma & 0 & 1 \\
\hline Metastasis & 3 & 0 \\
\hline Ganglioneuroma & 2 & 0 \\
\hline Pheochromocytoma & 4 & 2 \\
\hline Pheochromocytoma + Ganglioneuroma & 0 & 1 \\
\hline Cyst & 1 & 1 \\
\hline Cystic lymhangioma & 1 & 0 \\
\hline Myolipoma & 1 & 0 \\
\hline Cortex carcinoma & 1 & 1 \\
\hline Nodular hyperplasia & 0 & 1 \\
\hline
\end{tabular}

adrenal metastasis were resected laparoscopically without any complication.

\section{DISCUSSION}

Over the last few decades, obesity has increased in the world posing new surgical difficulties. Obesity is commonly regarded a risk factor for surgical complications, even though many studies have shown contradicting results (14-19).

The difficulties of surgical procedures in obese patients have been previously described. There are concerns regarding laparoscopic adrenalectomy (LA) in morbidly obese patients because of the associated limited working space and increased risk of postoperative complications (20). Studies have shown comparable peroperative and postoperative results in obese versus non-obese patients after laparoscopic operations (laparoscopic appendectomy, cholecystectomy, hernia surgery, colorectal surgery and antireflux surgery) (21-25). It is unclear why complication incidences vary in LA, this differrence may be due to specific organs that are manipulated in the course of operation. Particularly, in left-sided adrenal tumors, splenic flexure mobilization is required, which may lead to spleen injury. This maneuver may be more difficult in obese patients due to increased adipose tissue.

In our study, we used the lateral transabdominal technique. The most important advantages of this surgical approach are wide surgical field visualization and allowing for the resection of larger adrenal tumors.

The aim of this study was to evaluate peroperative and postoperative LA results in obese and non-obese patients. In 51 consecutive patients, Erbil et al have found a positive correlation between BMI and operating time, postoperative complications and hospital stay, suggesting that increased amount of adipose tissue is responsible for these findings (26). On the other side, Inaishi et al. have found that there were not statistically signifi- cant differences between obese and non-obese patients in operation time, length of hospital stay, conversion to open surgery (16). They have also determined that there were no statistically significant diferrences in perioperative and postoperative results of obese and non-obese patients; however, BMl $\geq 25 \mathrm{~kg} /$ $\mathrm{m}^{2}$ was the obesity criterion in their study which was a limiting factor (16). Dancea et al. have showed no statistically significant difference regarding age and operating time, but showed statistically significant difference in peroperative and early postoperative complications between obese and non-obese groups. (27). In our study, there was no statistically significant difference between groups in operating time, peroperative complications and length of hospital stay, but for the postoperative complications there was statistically significant differrence between the two groups. In the obese group, three patients required blood transfusion postoperatively (two patients whose operation were completed laparoscopically and one patient who needed conversion to open) due to massive hemorrhage during operation. There was pleural effusion in two patients whose operations were completed through conversion to laparotomy (right subcostal incision). These patients reported more pain that limited effective respiratory exercise. One of the laparotomy patients had deep vein thrombosis possibly due to immobility. One laparoscopy patient had unexplained microembolism of the upper extremity. In the obese group, one patient whose operation was completed laparoscopically, had Clavien-Dindo class 5 (patient died due to cardiopulmonary arrest) complication.

In this study, conversion to open surgery was high in the obese group, but with rates similar to conversion rates in other related studies. In the literatüre, the most common peroperative complication of LA is bleeding, which is also the most common reported reason for conversion to open surgery (27-29). In our study, the reasons of conversion were dense adhesions in two 
patients who had previously undergoneabdominal surgery, laparoscopically intractable hemorrhage in two patients (one patient in each of the groups) and one case of inferior vena cava injury. In one patient, it was difficult to differentiate the separate the tail of the pancreas from left-sided adrenal tumor (2.1 $\mathrm{cm})$. Before the surgery, surgeons should carefully evaluate the patients for previous laparotomies and the adrenal mass size. In obese patients, the surgeon may face the challenge of differentiating small size adrenal mass from adipose tissue or may even confuse the tail of the pancreas with the adrenal tissue of similar appearance. Before the resection of the adrenal tumor, anatomic landmarks such as pancreatic tail, aorta, medial and inferior adrenal artery, renal artery, renal vein should be well mapped for left-sided resection. For the right-sided resection, inferior vena cava, median, superior and inferior adrenal artery and vein should be expored as important anatomic landmarks.

Although the rate of conversion to laparotomy was higher in the obese group $(n=4,11.7 \%)$ when compared to the nonobese group ( $n=1,3.3 \%$ ), the reasons for conversion to laparotomy were not directly related to obesity. Conversion to laparotomy was directly linked to obesity in only one patient, in whom it was difficult to tell apart the tail of the pancreas and a small mass of the adrenal gland obscured by dense adipose tissue. In our study, most of the perioperative complications were due to previous laparotomy not obesity.

Our study has several limitations. First, this was a single-center study with a retrospective design. Second, there were small number of patients causing relatively high conversion rate in the obese group.

\section{CONCLUSION}

Obesity has no influence on operation time, preoperative complication and length of hospital stay. In obese patients, technical difficulties may be encountered during surgery due to increased adipose tissue, and postoperative complication rates may increase. Nevertheless, laparoscopic transperitoneal adrenalectomy can be performed safely in obese patients paying attention to the management of obesity-related complications.

Ethics Committee Approval: This approval for this study was obtained from Kartal Dr. Lütfi Kırdar Training and Research Hospital Clinical Research Ethics Committee (Decision No: 2019/514/146/4, Date: 28.01.2019).

Peer-review: Externally peer-reviewed.

Author Contributions: Concept - Ö.A.; Design -R.S.; Supervision - Ö.A.; Data Collection and/or Processing - Ö.A.; Analysis and/or Interpratation - R.S.; Literature Review - Ö.A.; Writing Manuscript - R.S.; Critical Reviews - Ö.A.

Conflict of Interest: The authors declare that they have no conflict of interest.

Financial Disclosure: The authors declared that this study has received no financial support.

\section{REFERENCES}

1. Gagner M, Lacroix A, Boite E. Laparoscopic adrenalectomy in Cushing's syndrome and pheochromocytoma. N Engl J Med 1992; 327(14): 1033. [CrossRef]

2. Saunders BD, Wainess RM, Dimick JB, Upchurch GR, Doherty GM, Gauger PG. Trends in utilization of adrenalectomy in the United States: have indications changed? World J Surg 2004; 28(11): 1169-75. [CrossRef]

3. Kim K, Kim JK, Lee CR, Kang SW, Lee J, Jeong JJ, et al. Surgical outcomes of laparoscopic adrenalectomy for primary hyperaldosteronism: 20 years of experience in a single institution. Ann Surg Treat Res 2019; 96(5): 223-9. [CrossRef]

4. Agha A, lesalnieks I, Hornung M, Philip W, Schreyer A, Jung $M$, et al. Laparoscopic trans- and retroperitoneal adrenal surgery for large tumors. J Minim Access Surg 2014; 10(2): 57-61. [CrossRef]

5. Chai YJ, Yu HW, Song RY, Kim SJ, Choi JY, Lee KE. Lateral transperitoneal adrenalectomy versus posterior retroperitoneoscopic adrenalectomy for benign adrenal gland disease: randomized controlled trial at a single tertiary medical center. Ann Surg 2019; 269(5): 842-848. [CrossRef]

6. Nomine-Criqui C, Demarquet L, Schweitzer ML, Klein M, Brunaud L, Bihain F. Robotic adrenalectomy: when and how? Gland Surg 2020; 9(Suppl 2): S166-S172. [CrossRef]

7. World Health Organization (WHO). Obesity. Available from: https:// www.who.int/topics/obesity/en/ (Accessed: 14.02.2019). [CrossRef]

8. Khoury W, Stocchi L, Geisler D. Outcomes after laparoscopic intestinal resection in obese versus non-obese patients. Br J Surg 2011; 98(2): 293-8. [CrossRef]

9. Kamoun S, Alves A, Bretagnol F, Lefevre JH, Valleur P, Panis Y. Outcomes of laparoscopic colorectal surgery in obese and nonobese patients: a case-matched study of 180 patients. Am J Surg 2009; 198(3): 450-5. [CrossRef]

10. Kazaure HS, Roman SA, Sosa JA. Obesity is a predictor of morbidity in 1.629 patients who underwent adrenalectomy. World J Surg 2011; 35(6): 1287-95. [CrossRef]

11. Kazaryan AM, Marangos IP, Rosok BI, Rosseland AR, Edwin B. Impact of body mass index on outcomesof laparoscopic adrenal surgery. Surg Innov 2011; 18(4): 358-67. [CrossRef]

12. Imber DA, Pirrone M, Zhang C, Fisher DF, Kacmarek RM, Berra L. Respiratory management of perioperative obese patients. Respir Care 2016; 61(12): 1681-92. [CrossRef]

13. Meijs AP, Koek MBG, Vos MC, Geerlings SE, Vogely HC, de GreeffSC. The effect of body mass index on the risk of surgical site infection. Infect Control Hosp Epidemiol 2019; 40(9): 991-6. [CrossRef]

14. Zonc"a P, Bužga M, Ihnat P, Martinek L. Retroperitoneoscopic adrenalectomy in obese patients: is it suitable? Obese Surg 2015;25(7): 1203-8. [CrossRef]

15. Chand M, De'Ath HD, Siddiqui M, Mehta C, Rasheed S, Bromilow J, et al. Obese patients have similar short-term outcomes to non-obese in laparoscopic colorectal surgery. World J Gastrointest Surg 2015; 7(10): 261-6. [CrossRef]

16. Inaishi T, Kikumori T, Takeuchi D, Ishihara H, Miyajima N, Shibata M, et al. Obesity does not affect peri- and postoperative outcomes of transabdominal laparoscopic adrenalectomy. Nagoya J Med Sci 2018; 80(1):21-8. [CrossRef] 
17. Ome Y, Hashida K, Yokota M, Nagahisa Y, Okabe M, Kawamoto K. The safety and efficacy of laparoscopic hepatectomy in obese patients. Asian J Surg 2019; 42(1): 180-8. [CrossRef]

18. Gregori M, Miccini M, Biacchi D, de Schoutheete JC, Bonomo L, Manzelli A. Day case laparoscopic cholecystectomy: safety and feasibility in obese patients. Int J Surg 2018; 49: 22-6. [CrossRef]

19. Mullen JT, Moorman DW, Davenport DL. The obesity paradox: body mass index and outcomes in patients undergoing nonbariatric general surgery. Ann Surg 2009; 250(1): 166-72. [CrossRef]

20. Ortenzi M, Balla A, Ghiselli R, Vergari R, Silecchia G, Guerrieri E, et al. Minimally invasive approach to the adrenal gland in obese patients with Cushing's syndrome Minim Invasive Ther Allied Technol 2019; 28(5): 285-91. [CrossRef]

21. Özozan ÖV, Güldoğan CE, Gündoğdu E, Özmen MM. Obesity and appendicitis: laparoscopy versus open technique. Turk J Surg 2020; 36(1): 105-09. [CrossRef]

22. Raakow J, Klein D, Barutcu AG, Biebl M, Pratschke J, Raakow R. Safety and efficiency of single-Incision laparoscopic cholecystectomy in obese patients: a case-matched comparative analysis. J Laparoendosc Adv Surg Tech A 2019; 29(8): 1005-10. [CrossRef]

23. Makino T, Trencheva K, Shukla PJ, Rubino F, Zhuo C, Pavoor RS, et al. The influence of obesity on short- and long-term outcomes after laparoscopic surgery for colon cancer: a case-matched study of $152 \mathrm{pa-}$ tients. Surgery 2014; 156(3): 661-8. [CrossRef]
24. Alizai PH, Andert A, Lelaona E, Neumann UP, Klink CD, Jansen M. Impact of obesity on postoperative complications after laparoscopic and open incisional hernia repair-a prospective cohort study. Int J Surg 2017; 48: 220-4. [CrossRef]

25. Tandon A, Rao R, Hotouras A, et al. Safety and effectiveness of antireflux surgery in obese patients. Ann R Coll Surg Engl 2017; 99(7): 515-23. [CrossRef]

26. Erbil Y, Barbaros U, Sari S, Agcaoglu O, Salmaslioglu A, Ozarmagan S. The effect of retroperitoneal fat mass on surgical outcomes in patients performing laparoscopic adrenalectomy: the effect of fat tissue in adrenalectomy. Surg Innov 2010; 17(2): 114-9. [CrossRef]

27. Dancea HC, Obradovic V, Sartorius J, Woll N, Blansfield JA. Increased complication rate in obese patients undergoing laparoscopic adrenalectomy. JSLS 2012; 16(1): 45-9. [CrossRef]

28. Tessier DJ, Iglesias R, Chapman WC, Kercher K, Matthews BD, Gorden $D L$, et al. Previously unreported high-grade complications of adrenalectomy. Surg Endosc 2009; 23(1): 97-102. [CrossRef]

29. Kazaryan AM, Marangos IP, Rosseland AR, Røsok BI, Villanger O, Pinjo E, et al. Laparoscopic adrenalectomy: Norwegian single-center experience of 242 procedures. J Laparoendosc Adv Surg Tech A 2009; 19(2): 181-9. [CrossRef]

\section{ORIJINAL ÇALIŞMA-ÖZET}

Turk J Surg 2021; 37 (2): 126-132

\section{Laparoskopik transperitoneal adrenalektomide obezitenin etkisi}

Önder Altın, Ramazan Sarı

Kartal Lütfi Kırdar Şehir Hastanesi, Genel Cerrahi Kliniği, İstanbul, Türkiye

\section{ÖZET}

Giriş ve Amaç: Laparoskopik adrenalektomi adrenal tümörlerin rezeksiyonu için altın standarttır. Ancak genel cerrahi pratiğinde nadiren rastlanııması, öğrenim eğrisinin yüksek olması gibi bazı teknik zorlukları vardır. Bunlara ek olarak, obezite de laparoskopik adrenalektomide bir başka sorundur. Biz bu çalışmamızda obezitenin laparoskopik adrenalektomide perioperatif ve postoperatif komplikasyonlara olan etkisini değerlendirmeyi amaçladık.

Gereç ve Yöntem: Çalışmaya Aralık 2008 ve Haziran 2018 tarihleri arasında opere edilen hastalar dahil edildi. Laparoskopik transperitoneal adrenalektomi uygulanan toplam 65 hasta vücut kitle indeksine (VKi) göre iki gruba ayrıldı. Hastaların demografik verileri, perioperatif ve postoperatif sonuçlarının kayıtları analiz edilerek gruplar karşılaştııılı.

Bulgular: Toplam 35 obez ve 30 obez olmayan hasta değerlendirildi. Obez ve obez olmayan hastalar arasında ameliyat süresi, peroperatif komplikasyonlar ve hastanede kalış süreleri açısından anlamlı fark yoktu. Ameliyat sonrası komplikasyonlar açısından ise iki grup arasında istatistiksel olarak anlamlı bir fark gözlendi $(p<0,031)$. Obez grubunda dört hastada, obez olmayan grupta ise bir hastada açık cerrahiye geçildi.

Sonuç: Obez hastalarda artan yağ dokusu nedeniyle ameliyat sırasında teknik zorluklarla karşılaşılabilir ve postoperatif komplikasyonlarda artış görülebilir. Buna rağmen obeziteye bağlı komplikasyonların yönetimine dikkat edilerek laparoskopik transperitoneal adrenalektomi güvenli bir şekilde uygulanabilir.

Anahtar Kelimeler: Adrenalektomi, vücut kitle indeksi, laparoskopi, obezite

Doi: 10.47717/turkjsurg.2021.4901 